УДК 130.1

DOI 10.35423/2078-8142.2021.1.2.05

А. В. Косинська, аспірантка Інституту філософії імені Г. С. Сковороди Наиіональної Академії Наук України, м. Київ, Украӥна e-mail: thecheapwhisky@gmail.com ORCID: https://orcid.org/0000-0002-9856-7616

\title{
СОЦАЛЬНИЙ ПОРЯДОК МІСТА У ФІЛОСОФСЬКИХ ТЕОРІЯХ: ВІД ГЕОРГА ЗІММЕЛЯ ДО МІШЕЛЯ ДЕ СЕРТО
}

У статті розглянуто місто з точки зору сочіального порядку від класичних сочіальних теорій до сьогодення. В основу покладено погляди Георга Зіммеля, механістична теорія Мамфорда Льюїса, ідея розподілу прачі Дюркгейма та місто як продукт культури Макса Вебера, за допомогою яких автор аналізує міську реальність Анрі Лефевра, соиіум спектаклю Гі Дебора та протиставлення стратегії та тактики в містах Мішеля де Серто. Поняття «соціальний порядок» стосується визначених обмежень, заборон та контролю у суспільній житті; має на увазі існування взаємин у суспільстві; включає в себе елемент передбачуваності та повторюваності у суспільному житті; може означати визначену узгодженість компонентів сочіального життя; відзначає стійкість, більш чи менш тривале збереження ї̈ форми. На трунті переосмислення міського життя зроблена спроба переосмислити соиіальний порядок, що є дотичним ідеям етнометодології. Метою статті є деталізація концепту міста в контексті конституювання та функиіонування соціального порядку та окреслення підстав для розвитку иьього аспекту в етнометодології Гарольда Гарфінкеля та його послідовників.

Ключові слова: сочіальний порядок, урбанізм, сочіальний простір, повсякденність міста, міські практики. 
Дослідження концепту міста у творах Георга Зіммеля, Макса Вебера, Мішеля де Серто, Гі Дебора та Анрі Лефевра порушує чимало філософських, соціологічних та політичних питань, пов'язаних з урбанізацією сучасного суспільства та особливим соціальним порядком нових поселень. У статті звертається увага на те, в який спосіб трактується місто з погляду соціального порядку від класичних до сучасних соціально-філософських теорій.

Засадничими у цьому сенсі є твори Г. Зіммеля, М. Вебера, В. Зомбарта, Е. Дюркгейма, а також О. Шпенглера і А. Тойнбі, які вважали місто ключовим феноменом розвитку людства. Важливо згадати теоретиків урбанізма, зокрема М. де Серто, А. Лефевра, Д. Джейкобс та С. Сассен. Звертається до теми міста і філософ техніки Мамфорд Льюїс у праці «Міф машини». Він доходить висновку, що у формуванні міста принциповим є суб'єктивний фактор, який впливає на ті чи інші функції міста, а також на появу/занепад його промислових зон [17].

Класик американського урбанізму Льюїс Мамфорд вважав, що добре місто - те, в якому соціальне життя максимально різноманітне та інтенсивне: «Міста будуються для посилення соціального життя і максимального збільшення його різноманітності» [17, с. 65]. Мамфорд наполягав на тому, що це розмаїття не варто зводити лише до позитивних явищ і процесів. Для здорового життя і розвитку міста важлива наявність конфліктів. Життя у великому місті завжди пов'язане $з$ досвідом агресивної поведінки, страхом та занепокоєнням. Страх може бути викликаний різними ситуаціями, вони можуть нести загрозу не лише життю або здоров'ю людини, а й іiі соціальному стану або самооцінці. Соціальний страх за інтенсивністю індивідуального переживання часом не поступається страхам екзистенційним. Страх - це точка збору солідарності. Жити спільно - закон виживання. Згуртованість допомагає нам у боротьбі з реальними та уявними небезпеками. Страх парадоксальним чином поєднує і роз'єднує нас.

Щодо українських досліджень, питання глобалізації та міської культури розглядали В. Горський, Н. Горська, В. Малахов. В. Срмоленко у праці «Оповідач і філософ: Вальтер Беньямін та його час» аналізує феномен міських пасажів і фланерування у фі- 
лософії В. Беньяміна. Не зважаючи на велику кількість досліджень міста, в них останнє розглядається здебільшого у контексті урбаністики. М. Карповець у праці «Місто як світ людського буття: філософсько-антропологічний аналіз» відзначає: «Філософськоантропологічне бачення проблеми особливо актуалізує та обставина, що вивчення міста як соціально-історичного явища донині відбувалося переважно у межах урбаністичних теорій. За цивілізаційного підходу місто розуміли як історичний феномен, основу якого становили соціально-правові та політичні відносини. Проте важливо також розглянути його у філософському контексті, долаючи таким чином однобічність цього підходу» $[13$, с. 1$]$.

На нашу думку, розуміння міста крізь призму соціального порядку, його принципів та відхилень від них, є невід'ємною частиною сучасної соціальної науки. Без осягнення механізмів конституювання соціуму неможливо наразі бути його частиною та існувати не лише фактично, а й практично та ефективно.

Метою нашої статті є 3'ясувати, в який спосіб соціальний порядок реалізується у місті у працях Зіммеля, Вебера, Дюркгейма, де Серто, Дебора та Лефевра.

Відповідно до визначеної мети поставлено завдання: віднайти та узагальнити наукові розвідки 3 теми; окреслити концепції «міста» Зіммеля, Вебера та Дюргейма; дослідити особливості соціального порядку в межах урбанізму де Серто, Дебора, Лефевра та ін.; окреслити властивості міста у соціальній філософії XX ст.

Для втілення поставленої мети і реалізації визначених завдань було використано такі загальнонаукові методи дослідження: логічний (було застосовано під час огляду історіографії дослідження), системно-структурний (стосовно характеристик міста), аналітико-синтетичний (вичленовування окремих властивостей «урбанізму» у різних авторів з метою формування переліку характеристик), історичний метод, метод аналізу наукової літератури, індукції (від окремих даних про розуміння «міста» до конституювання соціального порядку), порівняння (втілене у пошуку дотичності між творами авторів) та узагальнення (у процесі встановлення загальних рис предмета дослідження та його особливостей).

Соціальний порядок - це філософсько-соціологічне поняття, що пояснює, з одного боку, в який спосіб суспільні відносини на- 
бувають форми, а 3 іншого - яким чином соціальні системи і їх елементи пов'язані у часі та просторі [19, с. 456].

Пояснення соціального порядку, того, як і чому існують суспільства, є однією з основних проблем соціальних наук. Існують два способи пояснення соціального устрою: соціоцентристський, що сягає праць Е. Дюркгейма, та погляд на соціум як на продукт людських дій та взаємодій, який обстоював М. Вебер та його послідовники.

Перший, пов'язаний також з Парсонсом та функціоналістською школою, зосереджується на ролі спільних норм та цінностей у підтриманні згуртованості суспільства. Для Е. Дюркгейма цей наголос випливав 3 його критики утилітарної соціальної думки, популярної особливо серед теоретиків соціальних та політичних питань. На його думку, «механічна солідарність» доіндустріальних суспільств спиралася на спільні переконання та цінності. Однак при появі індустріального суспільства виникає новий спосіб «органічної солідарності», заснований на взаємозалежності, що $є$ наслідком соціалізації та диференціації. Моральні обмеження егоїзму виникають 3 асоціації та становлять основу соціальної згуртованості. Хоча Дюркгейм не заперечував існування конфліктів та застосування сили, особливо в періоди стрімких соціальних змін, Парсонс підкреслював важливість попереднього морального консенсусу як необхідної передумови соціального порядку. Через важливість, яку він надавав спільному переліку норм і цінностей, Парсонса наполегливо критикували за надмірний наголос на консенсусі, а також за нехтування конфліктами та змінами у своїх соціологічних аналізах [19, с. 235].

Друге пояснення соціального устрою походить від теорії соціальної дії М. Вебера та пропонує іншу версію розвитку соціальної думки. Вплив будь-якої особи зводиться до невтручання або до терплячого прийняття, яке за передбачуваним дійовою особою або дійовими особами змістом співвідноситься з дією інших людей або орієнтується на нього.

Щодо теорії міста, у різні часи чимало дослідників зверталися до цієї теми, розглядаючи його з різних філософських позицій. Г. Зіммель, Е. Дюркгейм, розробляючи власні соціальні теорії, ви- 
вчали місто. А М. Вебер був одним із перших, хто присвятив кілька грунтовних праць причинам виникнення міста, сутності та особливостям розвитку, зокрема відзначимо такі дослідження, як «Місто», «Господарство та суспільство», а також «Протестантська етика та дух капіталізму».

Георг Зіммель - засновник формальної соціології, в якій головну роль відіграють надбудови та логічні зв'язки, визначення окремих форм суспільного життя та дослідження їх. Такі форми Зіммель називає «формами соціацій» - структурами на базі взаємодії індивідів та груп. Кожна $з$ таких взаємодій має дві характеристики, а саме: форму та зміст.

Історія суспільства - це історія зростання інтелектуалізації, раціоналізації соціального життя і поглиблення впливу принципів грошових відносин. Інтелектуалізм і грошове господарство - це засадничі поняття концепції Зіммеля, яким він присвятив працю «Філософія грошей» [14]. Гроші, як і інтелект, розвиваються паралельно зростанню свободи і індивідуалізації членів соціальних груп, що зростає. Природу речей, як вважає Зіммель, вбивають гроші. Коли річ починають розглядати й оцінювати з точки зору вартості, вона випадає 3 категорії предметів 3 власним змістом, іiі якісна цінність переходить у кількісну. Зіммель відзначає: «Гроші запитують тільки про те, що $є$ загальним для усіх відповідних явищ, а саме про мінову вартість, яка нівелює будь-яку якість i оригінальність під єдиний критерій кількості» [14, с. 137].

На думку Зіммеля, об'єктивність - це сутність сучасної культури: об'єктивність грошей, що протистоїть суб'єктивній характеристиці володіння, що робить речі абсолютно незалежними від тієї чи іншої можливості їх застосування; об'єктивність логічних форм, що існують незалежно від змісту 3 формальною правильністю будь-якого, навіть безглуздого і помилкового судження. Такі парадокси і визначають, на думку вченого, сенс індустріальної епохи.

Великі міста $є$ головною ареною культури, що переростає все особисте. Тут у будівлях і навчальних закладах, у магії та комфорті техніки, у способах суспільного життя і зовнішніх державних інститутах позначається така переважна маса кристалізованого, знеособленого духу, що перед ним особа, можна сказати, є цілком безсилою. Життя для неї стає, з одного боку, нескінченно легким, 
тому що з усіх боків напрошуються збудження та інтереси, все для заповнення часу і думок, і це постійно тримає іiі у потоці, де плавцеві ледь потрібно робити якісь рухи. Але, з іншого боку, життя індивіда складається дедалі більше 3 такого безособового змісту і матеріалу, який має на меті придушити специфічне особистісне забарвлення і оригінальність.

Цінність суспільства, вважає Зіммель, полягає не в його власному функціонуванні і не у створенні об'єктивної культури, а у реалізації індивіда. Поряд з «трагедією культури» $є$ і «громадська трагедія». Оскільки, з одного боку, індивід повинен створювати необхідні соціальні форми і діяти в них, а з іншого - чим вищим $\epsilon$ його розвиток, тим меншим він вступає в них і знаходить співвіднесеність лише з фрагментами самого себе, лише у своїй площині. Філософія індивідуальності і соціологія взаємодіють та перемежовуються в усій творчості автора. Темою соціології є соціальні форми $з$ різними соціальними «дистанціями».

Якщо людина $\epsilon, з$ одного боку, виключно продуктом суспільства, то, з іншого, вона у своїй поведінці не $\epsilon$ цілком суспільно детермінованою. Якщо індивід вважає себе «продуктом суспільства» $\mathrm{i}$ «членом суспільства», тоді і соціологія може обрати для себе в якості відправної точки і те, і інше, до того ж «зміст» буде однаковим. «Щоб локалізувати (anordnen) існування індивіда, зрозуміти його, можна обрати точку зору як зсередини, так і ззовні; тотальність життя з усім ії соціально виведеним змістом може бути осягнута як така, що спрямована до центру долі ії носія (das zentripetale Schicksal seines Tragers), але так само і життя, з усім тим у ньому, що $є$ невід'ємним від індивіда, можна вважати продуктом і елементом життя соціального» [5, с. 28]. Отже, з одного боку, якщо соціальне (das soziale Geschehen) можна розглядати під кутом зору соціального порядку або форм взаємодії, то, з іншого, його можна аналізувати і в категорії одиничного життя.

Таким чином, у Зіммеля йдеться про мікросоціологію, яка на відміну від сучасних йому підходів покликана замінити соціальну дію, що конституює мікрорівень, переживанням. Макросоціологія захоплює лише частину сфери дії індивідів. В аналогічний спосіб вона захоплює лише частину міжіндивідуального соціального (des 
transindividuellen Gesellschaftlichen) і розглядає примус від соціальних структур як загрозу для індивіда (сюди ж зараховуємо і примус бути індивідуальністю).

Концепцію Е. Дюркгейма щодо поділу праці у формуванні міста можна назвати однією 3 методологічних підстав більшості праць сучасних авторів, що займаються урбаністською соціологі$\epsilon ю$.

Е. Дюркгейм обгрунтовує ідею соціології як науки, яка має власні методи і розглядає суспільство як реальність, що визначає межі людської поведінки. Центральна проблема у творчості Дюркгейма - це проблема соціальної солідарності. Згідно з його вченням, солідарність грунтується на поділі праці. Існує два історичних типи солідарності. Перший - механічна солідарність, або солідарність за схожими ознаками, за якою всі індивіди виконують однакові функції і не мають індивідуальних рис. Цей тип солідарності, на думку автора, спостерігається в архаїчних суспільствах.

Як суб'єктивну складову соціальної поведінки Дюркгейм вирізнив групу соціальних норм, що примусово організують поведінку індивідів. Як наслідок виникають соціальні взаємозв'язки: сімейні, родові, державні, економічні тощо. Свідомість, яка утворює сутність соціальної діяльності, являє собою як предмет соціологічного аналізу, так і головний зміст суспільного розвитку. Відтак, сукупність вірувань і почуттів членів одного і того самого суспільства утворює певну систему, що має своє життя, яку можна назвати колективною або загальною свідомістю. Вона хоча і реалізується індивідами, є, однак, чимсь іншим, окремим та унікальним. «Дійсно, з одного боку залежність від суспільства людини тим більша, чим більший поділ праці, з іншого ж боку діяльність будького тим більш особиста, чим біль спеціальна» [12, с. 29].

Е. Дюркгейм розглядав міста як місця зосередження соціальної маси і поділу праці. Він стверджував, що поділ праці є основою урбанізації та індустріальної епохи в цілому, саме у розвитку яких і формується новий тип солідарності. Розвиваючи цю думку у дослідженні «Про поділ суспільної праці», він протиставив два типи солідарності - механічну і органічну - і встановив їх зв'язок з поділом праці. Автор прогнозував поширення солідарності у сучасному суспільстві, однак зауважував, що перехід до неї супроводжува- 
тиметься руйнуванням традиційного соціального контролю, а отже - і знаного раніше соціального порядку.

М. Вебер, своєю чергою, виводить «розуміючу соціологію», таку, що звертається до розуміння поведінки людей. Він вважає, що метою соціологічної науки є аналіз соціальної дії і обгрунтування причин іiі виникнення. Розумінням у даному контексті позначається процес пізнання соціальної дії через сенс, який вкладає в дію сам суб'єкт. Соціальною дією, за Вебером, вважається дія, яка за змістом співвідноситься 3 діями інших людей і орієнтується на них. Так, Вебер вирізняє дві ознаки соціальної дії: осмислений характер та орієнтацію на очікувану реакцію інших. Таким чином, предмет соціології становлять усі ідеї і світогляди, які детермінують поведінку людини. Вебер відмовився від спроб використання природно-наукового методу в аналізі і вважав соціологію «наукою про культуру» [7, с. 234].

У праці «Місто» дослідник розглядає місто як місце, в якому можна побачити багато ключових рис сучасної урбанізованої території, а саме - зростання бюрократії, змінюваний уряд і демократію. Серед головних ознак міста він відзначав такі: регулярний обмін між місцевим та іншим населенням, отримання прибутку і задоволення потреб мешканців, наявність товарно-грошових відносин і ринку. Крім того, автор одним із перших довів, що необхідним наслідком міського способу життя $є$ зниження ймовірності особистісних контактів.

Місто для М. Вебера - це особливий спосіб життя, зумовлений ціннісно-світоглядними інтенціями людей. Стародавні міські поселення трансформувалися в європейські міста у результаті зміни ціннісно-світоглядних орієнтацій людей, появи нового типу культури - раціональної. Місто, за Вебером, почалося з культури, а не $з$ економіки. Місто в господарському сенсі він пропонує відрізняти від міста в адміністративно-політичному сенсі. У першому правлять ринок і гроші, а в другому - фортеця, гарнізон і наймана армія [7, с. 26].

Анрі Лефевр зміщує акценти з простору міста на процеси його створення. Він стверджує, що це суспільне виробництво міського простору є фундаментальним для відтворення суспільства, а от- 
же, і самого капіталізму. Процес урбанізації та соціальні проблеми міста стали засадничою темою для автора, який робить спробу переосмислення соціального порядку як такого. У Лефевра читаємо: «Поняття простору не може існувати окремо і лишатися статичним. Воно набуває діалектичного характеру: це продукт-виробник, підгрунтя економічних і соціальних відносин. Можливо, воно включається також у відтворення виробничого механізму, в розширене відтворення відносин, яке реалізується на практиці» $[1$, c. 1$]$.

Місто є результатом творення, виробництва та відтворення соціальних відносин. Таку думку автор наводить у «Праві на місто» і розвиває ії у «Виробництві простору».

Концепція простору Лефевра грунтується на трійці:

- просторова практика, що містить виробництво та відтворення, відведені місця та просторові множинності, що властиві кожній просторовій формації, яка забезпечує послідовність та відносну зв'язність;

- репрезентації простору, пов'язані з виробничими відносинами, з порядком, який вони встановлюють, і знаннями, знаками, кодами та прямими стосунками;

- простори репрезентації, які пропонують складну символіку, пов'язану з таємною підпільною частиною суспільного життя, а також 3 мистецтвом, яке в такому разі можна окреслити не як код простору, а як код простору репрезентації [1, с. 47].

Природа розмивається і стає вторинною. На перший план виходить соціальний характер простору, що не робить його зрозумілішим, навпаки - доводить до парадоксу. «Соціальний простір $\epsilon$, безперечно, простором забороненого. Його сповнюють заборони і доповнюють приписи. Чи можна вивести з цього факту якесь глобальне визначення? Нi! Простір - це не лише простір «ні», а й простір тіла, тобто і простір «так», життя» [2, с. 201]. Він намагається вийти за межі безпосередньої сутності. У ньому все, що було, стає опорою того, що буде. Первинна природа існує у природі вторинній - міській реальності. Простір міста $є$ ідеальним місцем для компромісу між згасаючим феодалізмом, буржуазією, олігархами, ремісниками. Це абстракція як вона є: віддалення від простору, 
протистояння загального особливому, універсальність, що виявляє та поглинає усе.

Автор пропонує два визначення поняття «міста». Перше: місто - це проекція суспільства на землі, тобто не лише окреслене місце розташування, а й простір, який сприймається та розуміється за допомогою думки, яка визначає матеріальний та соціальний складники. Друге: місто - це сукупність відмінностей між містами [3, с. 54]. Лефевр вважає за потрібне залишити друге визначення, оскільки перше не включає особливостей міст, що стали результатом їх історичного розвитку, наслідків розподілу праці між містами та взаємодії з навколишньою територією, яка може спричиняти суттєві розбіжності.

Місто розглядається як простір невідповідності між бажаним та можливим, що особливо яскраво реалізується у суспільстві споживання та призводить до відносної депривації. Вплив міста може простягатися далеко за його межами. Сучасне місто, як центр узгодження рішень, є бажаним місцем, через що може дозволити собі експлуатацію суспільства загалом, примушуючи його працювати на себе.

На думку Лефевра, дослідження повсякденності потрібне, щоб осягнути структурні порушення соціального простору. Для автора, як і для Гегеля, звичне не є пізнане. Аналіз повсякденності дає можливість осягнути нетривіальне у тривіальному. Звернення до конкретних соціальних практик відходить від сприйняття простору як пасивної статичної поверхні. Простір - це те, що колонізують та споживають, купують та продають, споживають та руйнують, те, над чим міркують і за що борються.

Дослідник пропонує визнати, що урбанізація - логічне завершення індустріалізації, тобто їх не можна розглядати окремо. Але міське життя не має підкорюватися чи залежати від промислового зростання. Обидва процеси мають бути контрольовані та керовані, щоб вибудувати урбаністичне суспільство. Місто має припинити бути пасивним резервуаром для продуктів виробництва. Воно має стати центром узгодження рішень містян.

Дещо інакше місто сприймає Гі Дебор, який виступає проти існуючих концепцій. Разом з молодими прихильниками антидер- 
жавних настроїв він сформулював методики дослідження міста, які виходили за межі утилітарного сприйняття мегаполісів. Контркультура протиставлялася капіталізму, а суспільство революції свідомості - суспільству споживання.

I анархісти, і ситуаціоністи критикували капіталізм, спираючись на соціальні зміни, пов'язані з революцією свідомості. Індивідуальна свідомість визначалася суспільством і сформованою культурою. Пізніше постала потреба в контркультурі, елементи якої повинні були змінювати індивідуальність. Той, хто не виробляв, а тільки споживав, був об'єктом критики. Виробництво в межах контркультурних ідей реалізовувалося, зокрема, за допомогою мистецтва. Саме в межах цього простору на перетині сміливих ідей того часу виникла психогеографія. «Наш вільний спосіб життя і навіть сумнівні розваги привертають увагу оточення. Ночівлі в будівлях, що підлягають знесенню; автостоп без зупинки і без місця призначення через Париж у межах транспортного страйку для посилення безладу; блукання у засекречених, закритих для простих смертних катакомбах і тому подібне - вираження емоційності, нічим не відрізняється від емоцій під час дрейфу. Викладені описи - не що інше, як пароль до цієї великої гри» [10].

У 1968 р. Гі Дебор видає працю «Суспільство вистави». Він називає виробництво засобів виробництва підставою суспільства, в якому вистава $\epsilon$ і результатом, і проектом способу виробництва: «Вистава одночасно $є$ і саме суспільство, і частина суспільства, i інструмент уніфікації. Як частина суспільства він явно виступає як сектор, що концентрує на собі всі погляди і свідомості. Однак, вже через те, що цей сектор є розділеним, він виявляється зосередженням помилкових поглядів і помилкової свідомості, а досягнена ним уніфікація - не чим іншим, як офіційною мовою загального поділу» [10, с. 13].

Вистава стимулює споживання, що створює гнучкі моделі способу життя, які вимагають безперервного участі у цьому процесі. Вистава - це стадія, на якій товару вже вдалося домогтися повної окупації суспільного життя. Відтепер ми бачимо тільки товар: видимий нами світ - це світ товару, де нівелюється відмінність між ним та цінностями, розвагами, витримкою. Наприклад, автомобільна вистава вимагає для себе хорошу транспортну мережу, яка 
мимоволі знищить старі міста, тоді як спектакль самого міста постає за збереження пам'яток старовини. За Дебором, щастя $є$ проблематичним, адже вимагає споживання всього одразу.

Таким чином, автор прирівнює виставу до Абсолюту, що віднімає у людини самостійність. Вистава трансцендентна світу, а отже, наше Я потребує іiі для свого існування. Дебор відзначає: «Урбанізм - це захоплення капіталізмом у власність людського і природного середовища; відтепер сам капіталізм, мірою логічного розвитку до свого абсолютного панування, може і повинен перебудовувати весь свій простір як власну декорацію» [10, с. 73]. Це найголовніша технологія поділу, ефективний засіб для збереження класової структури влади. Тривалий час влада вела боротьбу за те, щоб не дати трудящим остаточно об'єднатися, урбанізм забезпечив успіх цієї боротьби.

Дебор стверджує, що саме ми спостерігаємо за саморуйнацією міського середовища. Диктатура автомобіля втілюється через панування автобанів, які розчленовують старі міські центри і вимагають ще більшого їх розсіювання. При цьому залишки міської структури зосереджено біля гігантських супермаркетів. «У сучасному суспільстві споживання $\epsilon$ всеосяжною релігією, існують храми споживання у вигляді супермаркетів або торгових комплексів, а суспільство приносить постійні жертви язичницькому богові, ім'я якому - Видовище» [10].

Як відзначає Дебор, самовизволення в нашу епоху полягає у позбавленні від матеріальної бази, на якій грунтується брехня сучасного світу. Цю місію можна доручити тільки класу, здатному стати руйнівником усіх класів. Елементом унітарного урбанізму Дебор вважає не будинок, а архітектурний комплекс як об'єднання усіх факторів - атмосферу або серію. 3 одного боку, жодна ситуація не схожа на іншу, а з іншого - життя людей у місті виглядає як сіра сукупність повторювань, тож автор пропонує створювати такі міські комплекси/атмосфери, які безпосередньо впливали б на якість життя та безпосередній сенс його моментів.

У автора знаходимо: «Психогеографія - це ігровий бік сучасного урбанізму. Через ігрове розуміння міста із середовищем ми прокладаємо шлях постійного будівництва майбутнього. Якщо 
на те воля, то психогеографія - це «наукова фантастика», але така, яка розкривається у фрагментах поточного життя і заздалегідь визначає всі свої ідеї до практичної реалізації, безпосередньо адресованої нам» [10, с. 97]. У цьому контексті варто згадати «Про деякі мотиви у Бодлера» Вальтера Беньяміна. Автор вивчає натовп як нове явище, зароджене у міському просторі у другій половині XIX ст.: потік незнайомців, що мотивуються приватними інтересами, нівелювання індивідуумів. Так виникає поняття фланера - персонажа, зайнятого святковими прогулянками, героя, якого цікавить натовп і вітрини магазинів, а комфортна середа для нього - міський ландшафт. Фланер протестує проти цілеспрямованого руху та ритму [6].

У цьому контексті слушним є розрізнення між тактикою та стратегією у межах міста Мішеля де Серто. Він розглядав суспільство та місто у своїй найбільш відомій праці «Винахід повсякденності». У ній автор скомбінував свої різнобічні наукові інтереси для того, щоб розробити теорію про продуктивну та виснажливу діяльність, властиву повсякденному життю. Відповідно до теорії Серто, повсякденне життя відрізняється від інших практик щоденного існування, оскільки воно є повторюваним. Центральна думка роботи - зміна перспективи погляду на місто, з реальної (з висоти хмарочоса) або уявної (картини, карти, проекти) висоти на життя в місті, освоєння жителями його простору в протистоянні урбаністичному устрою правлячих інстанцій. На прикладі способів «гуляти», «дивитися», «називати» місто, автор, переходячи від опису власних суб'єктивних вражень до історичних екскурсів і семіотичного аналізу, зображує простір як місце боротьби «тактик» $\mathrm{i}$ «практик» соціальних агентів структур влади. «Поступово репрезентації, які ще донедавна належали до родини, групи і соціального порядку, йдуть зі сцени, на якій вони панували донині. Сьогодні тут $\epsilon$ число - число демократії, великого міста, адміністрування, кібернетики. Це гнучка і нескінченна маса, щільно виткана, як матерія без розривів і швів, це безліч кількісно певних героїв, які втрачають імена і особи, стаючи рухомою мовою підрахунків і раціоналізації, що не належить нікому. Це вуличні потоки, перетворені на цифри» $[18$, с. 62]. 
Де Серто приділяє особливу увагу відмінності понять «стратегія» і «тактика», їхньому протистоянню. Він пов'язує поняття «стратегія» 3 інститутами і структурами влади, тоді як «тактика» використовується особистістю, щоб створити вільний особистий простір в оточенні, яке визначається стратегіями: «Тактика - це мистецтво слабкого... Міць пов'язана зі зримістю. Протилежним чином, хитрість виявляється можливою для слабкого і часто-густо тільки вона і є для нього можливою, стаючи «останнім притулком»: чим більше сили, підлеглі стратегічному керівництву, виявляються у порівнянні зі своїми завданнями слабкими, тим більше стратегічне керівництво буде схильне до хитрощів. Я сказав би: тим більше стратегія перетворюється на тактику» [18, с. 73].

Дослідник описує поняття «місто» як концепт, вироблений стратегічним маніпулюванням органів уряду, корпорацій та інших громадських інститутів, які виробляють своєрідні мапи, що описують місто як чорну діру з висоти пташиного польоту. У своїх працях де Серто намагається підкреслити шлях, яким особистості несвідомо спрямовують усе: від міських вулиць до літературних текстів. Ось як автор розуміє місто:

«Місто, засноване утопічним чи урбаністичним дискурсом, окреслюється потрійною операцією:

- Виробництвом власного простору: раціональна організація повинна усувати всі фізичні, розумові або політичні вади, які могли б їі скомпрометувати.

- Заміщенням невловимих і наполегливих видів опору традиції не-часом, або синхронічною системою: урятовані від усякої неоднозначності наукові стратегії, що стали можливими завдяки розподілу всіх даних на площині, повинні замінити собою тактики користувачів, які отримують вигоду від «зручних випадків» і які, за рахунок цих подій-пасток, цих сліпих плям, відкривають дорогу непроникності історії.

- Нарешті, створенням універсального і анонімного суб'єкта, яким є саме місто: поступово стає можливим приписати йому, як i державі Гоббса, його політичної моделі, всі функції і предикати, донині розсіяні серед безлічі реальних суб'єктів, груп, асоціацій і індивідів. Таким чином, «місто», подібно до імені власного, дає 90 
можливість мислити і створювати простір, виходячи 3 кінцевої кількості стійких, ізольованих і взаємопов'язаних властивостей» [18, c. 73].

Розглядаючи проблематику міста, неможливо не згадати Джейн Джекобс. Одна з найбільш знаних дослідниць урбаністики, Джекобс у праці «Життя та смерть великих американських міст» розглядає різні приклади з реальної історії США, коли чітко сплановані та архітектурно вибудовані міста не рідко «вмирають», адже сучасне місто має бути неспинним, живим та керованим спонтанним порядком. Ця праця - намагання проаналізувати місто зсередини, $з$ точки зору людей, які будують простір та сповнюють його суспільним життям [11]. На думку Джейн Джекобс, живе і piзноманітне місто, засноване на спонтанному порядку і різних механізмах саморегулювання, в усіх відношеннях $є$ більш придатним для життя, ніж реалізація будівної теорії, хоч би якою продуманою та раціональною вона виглядала.

У працях дослідниці вперше були послідовно сформульовані принципи, які висувають на перший план зручне повсякденне життя городян, а не абстрактний урбанізм. Свої ідеї Джекобс підкріплювала «тактичними методами»: закликала до субсидування житла, порятунку житлових і нежитлових районів. I, звичайно, іiі хвилювала проблема міської екології: «Конче потрібно, щоб люди навчилися розуміти міську екологію якнайкраще. Почати можна 3 будь-якої точки міських процесів» [11].

Ефективне містобудування у великих містах, відзначає Джекобс, має виконувати такі завдання:

- сприяти появі живих і цікавих вулиць;

- підкреслювати функціональну ідентичність, самобутність території;

- робити так, щоб вулична тканина була якомога більш суцільною на всій території району;

- використовувати парки, площі, сквери та громадські будівлі як частини цієї вуличної тканини; використовувати їх для збіль-

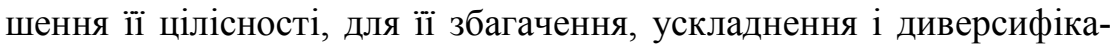
ціï. 
Великі міста - природні генератори різноманітності та щедрі інкубатори нових починань і всіляких ідей. У зв'язку з цим автор вирізняє кілька умов, які сприяють генерації різноманітності на вулицях і в районах великих міст:

- квартали здебільшого мають бути короткими. Це означає, що вулиці та можливості повернути за ріг повинні бути частими;

- у районі повинні, попереджаючи, йти будівлі, що розрізняються за віком і станом, включаючи чимало старих, щоб принесені ними економічні плоди були різними. Це змішання повинно бути досить тісним;

- потрібна досить висока концентрація людей, хоч би з яких причин вони тут знаходилися. Зокрема - висока концентрація людей, що живуть у даному районі [11].

Цікаво, що Джейн Джекобс дає практичні поради щодо влаштування великих міст, наводячи численні приклади та посилаючись на інших теоретиків. Важливим $є$ те, які розумові звички вона вирізняє для розуміння великих міст: думати в категоріях процесів; міркувати індуктивно, йдучи від часткового до загального, а не навпаки; шукати не опосередковані ключі до вирішення, пов'язані 3 малими величинами, а такі, що допомагають зрозуміти, в який спосіб функціонують більші й більш опосередковані величини.

Цей підхід розвинуто в етнометодології. Гарольд Гарфінкель вважає, що розуміння соціального життя індивідами конституюється, так би мовити, зсередини. Це означає, що соціальний порядок $є$ продуктом власної спонтанної активності індивідів, який виходить саме таким, яким його створили конкретні учасники соціальної взаємодії - звісно, з урахуванням раніше набутих правил і знань, отриманих від їхньої культурної групи в межах того самого міста. Відтак, локальне виробництво соціального порядку людьми, що володіють власною, за словами Гарфінкеля, «практичною раціональністю», - це ключовий постулат етнометодологіi.

Соціальна структура впливає на свідомість індивіда через «фонові очікування», тобто соціально схвалювані установки на ті чи інші дії, які можуть не усвідомлюватися і не піддаватися рефлексії самих акторів. Однак вони не пасивно сприймаються: індивіди надають їм особистісний, практично раціональний сенс, перероб- 
ляють, а іноді й істотно деформують. Відтак, соціальне життя представляється впорядкованим у певному вигляді лише тому, що члени товариства активно зайняті наданням сенсу всьому тому, що відбувається в процесі інтеракцій. А завдання етнометодологіі полягає в тому, щоб показати механізм людської активності в контексті конституювання мінливої соціальної дійсності, виходячи в результаті на вивчення фонових очікувань [6].

На вченні Гарфінкеля розробка соціального порядку в етнометодології не припиняється. Його послідовниця Ен Роулз демонструє, що зрозумілий порядок має конститутивний та контингентний характер. Авторка пропонує вирізняти два типи порядку: конституйований та інституційний або агрегований.

Доходимо висновку, що місто - це осередок культурного розвитку та основа держави та культури. Принциповими для цієї теми стали праці Г. Зіммеля та М. Вебера, які ми розглядали як підгрунтя для розуміння сучасних урбаністичних поглядів А. Лефевра, Г. Дебора та М. де Серто.

За Зіммелем, місто є простором реалізації сучасного життя у найкращому та найнегативнішому змісті. Для Макса Вебера, який грунтувався на ідеї розподілу праці Дюркгейма, місто - це особливий спосіб життя, зумовлений ціннісно-світоглядними інтенціями людей. На його думку, місто почалося з культури, а не з економіки. Гі Дебор розглядає соціум через концепцію спектаклю, який дорівнює Абсолюту, віднімає у людини самостійність. Анрі Лефевр зосереджує увагу на місті, яке є результатом творення та відтворення будь-яких соціальних відносин. Міська реальність $є$ другою природою і ідеальним місцем для компромісу між згасаючим феодалізмом, буржуазією, олігархами, ремісниками. Відтак, необхідним є дослідження повсякденності заради осягнення зрушень соціального простору. Мішель де Серто описує поняття «місто» як концепт, вироблений маніпулюванням органів уряду, корпорацій та інших громадських інститутів, які описують місто як «чорну діру» 3 висоти пташиного польоту. Сучасне місто дає можливість мислити i створювати простір, виходячи з окресленої кількості стійких, ізольованих і взаємопов'язаних властивостей.

Поняття «соціальний порядок» має відношення до визначених обмежень, заборон та контролю у суспільному житті; має на 
увазі існування взаємин у суспільстві; включає в себе елемент передбачуваності та повторюваності в суспільному житті; може означати визначену узгодженість компонентів соціального життя; вказує на стійкість, більш чи менш тривале збереження пї форми. На грунті переосмислення міського життя відбуваються спроби переосмислити соціальний порядок, що дотичне ідеям етнометодологiï.

Етнометодологія демонструє, що правила не працюють автоматично, що їх втілюють у життя люди, які діють у конкретних ситуаціях, де правила співвідносяться $з$ локальними обставинами. Хоч би яку повсякденну практику ми взяли, вона може бути проаналізована сама по собі. У будь-якому епізоді життя в тому самому місті застосовується стільки методів і вони настільки детальні, що ми ніколи не зможемо їх помітити, якщо не почнемо ретельно і детально описувати дії людей у реальній ситуації.

Фонові очікування задають індивідам напрям соціальної взаємодії, характер комунікації, залишаючи при цьому можливість для власної творчої активності. Пересічний індивід, не усвідомлюючи цього, у своїй повсякденній діяльності стає суб'єктом соціальної взаємодії і творцем соціальної реальності. Саме фонові очікування, вважає Гарфінкель, $є$ фундаментальними латентними структурами суспільного життя, які можуть вивчатися практично лише за допомогою запропонованих ним методів етнометодології.

Таким чином, місто є наразі актуальною темою у філософії. Починаючи із Зіммеля та Вебера, до проблематики урбанізму звертаються в різні часи у контексті соціології, антропології, культурології та архітектури. Його концепт від зосередження грошей та промисловості змінився до зростання соціальних просторів, а згодом - i до їхньої руйнації. Таким чином, поняття міста, з огляду на історичні процеси, поглиблювалося та поширювалося, ставало щодалі складнішим. Процес цей стає надалі актуальнішим, адже XXI століття ми можемо і маємо вважати урбаністичним. 


\section{ЛIТЕРАТУРА}

1. Lefebvre H. The Production of Space. Oxford: Blackwell, 1991. 454 p.

2. Lefebvre H. Critique of Everyday Life. Vol. 1. London: Verso, 1991. 283 p.

3. Lefebvre H. Le droit a la ville. Paris : Anthropos, 1968. 642 p.

4. Elden S. Understanding Henri Lefebvre. Theory and the Possible. London, New York : Continuum, 2004. 272 p.

5. Simmel G. Soziologie. 4. Aufl, Berlin, 1958.

6. Беньямин В. О некоторых мотивах у Бодлера (отрывок) / пер. А. Магуна. Синий диван. 2002. № 1. С. 107-124.

7. Вебер Макс. Город / пер. с нем. Б. Н. Попова, ред. Н. И. Кареев. Петроград : Наука и школа, 1923. 136 с.

8. Гарфинкель Г. Исследования по этнометодологии / пер. с англ. 3. Замчук, Н. Макарова, Е. Трифонова. СПб. : Питер, 2007. 336 с.

9. Гумбрехт Х.-У. Производство присутствия: Чего не может передать значение. Москва : НЛО, 2006. 183 с.

10. Дебор Ги Эрнест. Общество спектакля. Москва, 1999. URL: https://ru.theanarchistlibrary.org/library/gi-debor-obschestvo-spektaklya.pdf

11. Джейн Джекобс. Смерть и жизнь американских городов. Москва : Новое издательство, 2015. 512 с.

12. Дюркгейм Е. Самогубство: Соиіологічне дослідження / пер. 3 фр. Л. Кононович. Київ : Основи, 1998. 519 с.

13. Дюркгейм Э. О разделении общественного труда / пер. с фр. А. Б. Гофмана. Москва : Канон, 1996. 432 с.

14. Зіммель Г. Філософія грошей. Київ : Фоліо, 2019. 667 с.

15. Карповець М. В. Діалектика публічного і приватного простору людського буття у світі міста. Вісник Черкаського університету. Серія «Філософія». 2011. Вип. 200. С. 52-59.

16. Карповець М. В. Місто як світ людського буття: філософськоантропологічний аналіз. Рукопис. URL: http://ekmair.ukma.edu.ua/bits tream/handle/123456789/2325/Karpovets\%20City\%20as\%20a\%20World\%20 \%20Referat.pdf?sequence $=1 \&$ isAllowed $=\mathrm{y}$

17. Мамфорд Льюис. Миф машины. Техника и развитие человечества / пер. с англ. Т. Азаркович, Б. Скуратов. Москва : 2001. $437 \mathrm{c}$.

18. Мишель де Серто. Изобретение повседневности. Искусство делать / пер. с фр. Д. Калугина, Н. Мовниной. СПб. : Изд-во Европейского университета в Санкт-Петербурге, 2013. 330 с. 
19. Новейший философский словарь / уп. А. А. Грицанов. Минск : Книжный Дом, 1999. 784 с.

20. Филиппов А. Социология пространства. СПб.: Владимир Даль, 2008. 285 с.

\section{REFERENCES}

Lefebvre, H. (1991). The Production of Space. Oxford: Blackwell.

Lefebvre, H. (1991). Critique of Everyday Life. Volume One. London: Verso.

Lefebvre, H. (1968). Le droit a la ville. Paris: Anthropos.

Elden, S. (2004). Understanding Henri Lefebvre. Theory and the Possible. London, New York: Continuum.

Simmel, G. (1958). Soziologie. Aufl, Berlin.

Benjamin, V. (2002). On some motives in Baudelaire (excerpt). A. Maguna (Trans.). Blue sofa, 1, 107-124. [In Russian].

Weber, M. (1923). City. B. N. Popov (Trans.). [In Russian].

Garfinkel, G. (2007). Research on ethnomethodology. Z. Zamchuk, N. Makarova \& E. Trifonova (Trans.). SPb.: Peter. [In Russian].

Humbrecht, H.-U. (2006). Production of presence: Which cannot convey meaning. Moscow: UFO. [In Russian].

Debord, G.-E. (1999). The Society of the Spectacle. Moscow. Retrieved from https://ru.theanarchistlibrary.org/library/gi-debor-obschestvo-spektaklya.pdf [In Russian].

Jacobs, J. (2015). Death and Life of American Cities. Moscow: New Publishing House. [In Russian].

Durkheim, E. (1998). Suicide: Sociological Doslidzhennya. L. Kononovich (Trans.). Kiev: Osnovi. [In Russian].

Durkheim, E. (1996). On the division of social labor. A. B. Hoffmann (Trans.). Moscow: Canon. [In Russian].

Zimmel, G. (2019). Philosophy of money. Kiev: Folio. [In Russian].

Karpovets, M. V. (2011). Dialectics of public and private space of human bootty near the light of the world. Visnik of the Cherkasy University. Series "Philosophy", 200, 52-59. [In Ukrainian]. 
Karpovets, M. V. Misto yak light of human boottya: philosophical and anthropological analysis. Retrieved from http://ekmair.ukma.edu.ua/bits tream/handle/123456789/2325/Karpovets\%20City\%20as\%20a\%20World\%20 $\% 20$ Referat.pdf?sequence $=1$ \&isAllowed $=y$ (date of seeing is $02 / 21 / 21$ ) [In Ukrainian].

Mumford, L. (2001). The myth of the machine. Technique and development of mankind. T. Azarkovich \& B. Skuratov (Trans.). Moscow. [In Russian].

Michel de, Certeau. (2013). The invention of everyday life. The art of doing. D. Kalugin \& N. Movnina (Trans.). St. Petersburg: Publishing house of the European University in St. Petersburg. [In Russian].

The latest philosophical dictionary. (1999). Minsk: Book House. [In Russian].

Filippov, A. (2008). Sociology of space. SPb.: Vladimir Dal. [In Russian].

\title{
Anastasiia Kosynska
}

Post-Graduate Student, H.Skovoroda Institute of Philosophy of the NAS of Ukraine; Kyiv, Ukraine; e-mail: thecheapwhisky@gmail.com; ORCID: https://orcid.org/0000-0002-9856-7616

\section{Social order of the city in philosophical theories: from Georg Simmel to Michel de Serto}

\begin{abstract}
The article deals with the city from social order in classical social theories to the modern concepts. The social order is one of the main problems of social sciences. There are two explanations of society: a social-centered one wich starts from Parsons's works, and a society as a product of human beings from Weber's theory etc. Author of thr article starts with the theory of Georg Simmel, the mechanistic theory of Mumford Lewis, the idea of labor division of Durkheim and the city as a product of the culture by Max Weber. The author analyzes the urban reality of Henri Lefebvre, the society of Guy Debord's performance and the opposition of strategy and tactics in the cities of Michel de Serto. The concept of «social order» refers to certain restrictions, prohibitions and controls in public life; implies the existence of relationships in society; includes an element of predictability and recurrence in public life; mean a certain coherence of the components of social life; indicates stability,
\end{abstract}


more or less long-term preservation of its shape. On the basis of rethinking urban life, there are attempts to understand the social order, which is related to the ideas of ethnomethodology. The goal of the work is to detail the concept of the city in the context of the constitution and functioning of the social order and to describe the grounds for the development of this aspect in the ethnomethodology of Harold Garfinkel and his followers. The author of the article thinks that the understanding of the city through the prism of the social order, its principles and characteristics is the important part of contemporary social science. Without an explanation of the mechanisms constituted by the society, it is not possible to be a part of it.

Keywords: urbanism, social space, everyday life, urban practices, social order. 